\title{
Studi Komparatif Pelaksanaan Peradilan Pidana Islam di Negara Republik Arab Mesir dan Negara Republik Indonesia (Provinsi Nanggroe Aceh Darussalam)
}

\author{
Annisa Rahmadiana \\ Fakultas Hukum, Universitas Padjadjaran
}

dikirim: 7 Agustus 2021

direvisi:25 Desember 2021

diterima: 27 Desember 2021

\begin{abstract}
Abstrak:
Artikel ini membahas mengenai pelaksanaan peradilan pidana islam di Indonesia khususnya di Provinsi Nanggroe Aceh Darussalam dan Negara Republik Arab Mesir. Antara Mesir dengan Indonesia memiliki acuan yang sama dalam pelaksanaan syariat islam dalam peradilannya yakni mengacu pada Al Quran dan Hadits. Mahkamah Syar'iyah Aceh memiliki kedudukan sebagai bagian dari lembaga peradilan khusus di bawah naungan peradilan umum dan peradilan agama sesuai dengan jenis perkara yang ditangani. Sedangkan Mahkamah di Mesir memiliki cakupan yang lebih luas dengan fungsi dan wewenang masing-masing sesuai dengan tingkatannya. Metode penelitian yang digunakan pada penyusunan artikel ini adalah studi komparatif dengan membandingkan persamaan dan perbedaan yang melekat pada Indonesia dan Mesir dalam hal pelaksanaan syariat islam yang diteliti melalui bahan bacaan antara lain berasal dari buku, peraturan perundang-undangan, dan berbagai sumber lain yang terkait.
\end{abstract}

Kata Kunci : Mahkamah, Peradilan, Hukum Islam, Aceh, Mesir.

\section{Abstract:}

This article discusses the implementation of Islamic criminal justice in Indonesia, especially in the Province of Nanggroe Aceh Darussalam and the Arab Republic of Egypt. Between Egypt and Indonesia have the same reference in the implementation of Islamic law in the judiciary, namely referring to the Qur'an and Hadith. The Aceh Syar'iyah Court has a position as part of a special judicial institution under the auspices of the general court and the religious court according to the type of case being handled. Meanwhile, the Court in Egypt has a wider scope with each function and authority according to its level. The research method used in the preparation of this article is a comparative study by comparing the similarities and differences inherent in Indonesia and Egypt in terms of the implementation of Islamic law which is studied through reading materials, including books, laws and regulations, and various other related sources.

Keywords : Court, Judiciary, Islamic Law, Aceh, Egypt. 
Morality : Jurnal Ilmu Hukum

\section{PENDAHULUAN}

Keberagaman negara di dunia juga menujukkan masing-masing ciri khas yang menimbulkan perbedaan khususnya mengenai lembaga peradilan. Nyatanya perbedaan lembaga peradilan yang digunakan atau diterapkan suatu negara sedikit banyak dipengaruhi oleh keberadaan garis sejarah yang dimiliki oleh masing-masing negara atau bahkan dipengaruhi keluarga hukum (legal family) yang dianut. Keluarga hukum merupakan suatu pengklasifikasian sistem hukum (legal system) yang keberadaannya digunakan untuk mempermudah mengetahui berbagai sistem hukum yang ada di dunia (Arief, 2019). Mengenai pembagian keluarga hukum, masingmasing ahli memiliki pandangannya sendiri. Rene David dan John E.C. Brierly memisahkan keluarga hukum menjadi enam istilah sistem hukum yakni RomanoGermanic Family, Family of Socialist Law, Muslim Law, Sistem Hukum Timur Jauh, Common Law Family, dan Sistem hukum Afrika dan Malagsy (Atmasasmita, 2000). Kemudian sedikit berbeda dengan pandangan ahli sebelumnya, Eric L. Richard membagi keluarga hukum menjadi beberapa jenis yakni Far East Law, Civil law, Socialist Law, Islamic Law, Sub
Sahara Africa, dan Common Law (Suherman, 2008).

Indonesia merupakan salah satu negara yang masuk ke dalam keluarga civil law sebagai sistem hukumnya. Penerapan sistem hukum ini bukan tanpa dasar, melainkan dipengaruhi hukum bawaan Belanda yang juga menganut civil law system. Akan tetapi hal yang demikian tidak membatasi sistem hukum lainnya untuk diterapkan di Indonesia, karena tidak terdapat larangan suatu negara untuk menerapkan beberapa sistem hukum sekaligus (Susi Dwi Harijanti, 2014). Oleh sebab itu, menjadi sah-sah saja bagi Indonesia untuk menerapkan hukum lainnya seperti hukum islam sebagai bagian dari hukum yang berlaku di samping digunakannya hukum bawaan Belanda. Sementara itu, berbeda dengan Indonesia, Republik Arab Mesir merupakan negara yang menjadikan islam sebagai agama negara serta hukum islam atau syariat islam sebagai sumber utama peraturan perundang-undangan yang tercermin dalam Pasal 2 Konstitusi Republik Arab Mesir Tahun 2014.

Berdasarkan uraian tersebut penulis tertarik untuk membandingkan penerapan hukum pidana islam di masing-masing negara, yakni Indonesia yang pelaksanaannya diwakili Provinsi 
Nanggore Aceh Darussalam dan Mesir. Metode yang digunakan dalam penulisan artikel ini adalah studi komparatif, yakni untuk menemukan persamaan dan perbedaan yang ada antara dua objek yang dijadikan perbandingan. Sebagaimana Sunaryati Hartono dalam pandangannya mengemukakan perbandingan sebagai tindakan mencari perbedaan-perbedaan serta persamaan-persamaan dengan memberi penjelasannya dan meneliti bagaimana berfungsinya hukum dan bagaimana pemecahan yuridisnya di dalam praktik serta faktor-faktor non-hukum yang dapat memengaruhinya (Sunaryati, 1976). Sejalan dengan pandangan tersebut, Black's Law Dictionary mengartikan perbandingan hukum sebagai suatu studi mengenai prinsip-prinsip ilmu hukum dengan melakukan perbandingan berbagai macam sistem hukum (Arief, 2019).

Tujuan dilakukannya perbandingan hukum dalam penelitian ini adalah untuk memberikan pemahaman yang lebih komprehensif mengenai sistem hukum itu sendiri (Glendon et al., 1994). Di samping itu, penggunaan perbandingan hukum mampu memperluas perspektif dengan melihat bagaimana sistem hukum lain menyelesaikan masalah yang serupa, serta mampu menjelaskan sejarah dan pertumbuhan hukum, perannya dalam masyarakat, juga hubungannya dengan perilaku dan gagasan. Jelasnya, membantu kita memahami dinamika perubahan sosial dan hukum. Sehingga timbul kegunaan yang sifatnya praktis maupun teoritis. Teoritis di sini dimaksudkan untuk mendukung perkembangan ilmu hukum pada umumnya dan hukum pidana pada khususnya. Ditentukan bahwa kegunaan ini meliputi dua hal, yaitu berkaitan dengan riset di bidang filsafat dan sejarah hukum serta berkaitan dengan pemahaman dan pengembangan hukum nasional. Sedangkan kegunaan yang bersifat praktis ini menunjukkan bahwa studi perbandingan hukum mampu memberikan input positif bagi pembentukan hukum pada umumnya ataupun hukum pidana pada khususnya. Lebih lanjut, berkenaan dengan perbandingan hukum ini dapat juga dipandang bermanfaat bagi perkembangan ilmu hukum dan pembaharuan hukum serta digunakan untuk menyelesaikan masalah hukum yang menyangkut peristiwa hukum dalam keadaan nyata atau dalam pembentukan hukum itu sendiri (Atmasasmita, 2009).

\section{PEMBAHASAN}

\section{A. Kedudukan Hukum Islam Masing-}

\section{Masing Negara}

Sejak lama ajaran agama islam menyebar di seluruh dunia hingga 
Morality : Jurnal Ilmu Hukum

mengantarkan penerapan hukum islam bagi para pemeluknya, tak terkecuali bagi Indonesia dan Mesir yang juga turut merasakan kehadiran islam. Masuknya agama islam di Mesir disinyalir telah terjadi sejak zaman Rasulullah masih hidup, namun demikian Mesir baru dapat dikatakan menjadi kota islam sejak abad ke-7 ketika Khalifah Umar bin Khatab memegang tampuk kepemimpinan umat islam menggantikan Abu Bakar. Sedikit lebih muda dibandingkan Mesir, ajaran agama islam baru masuk ke Indonesia sejak abad ke-13 melalui pedagang Arab dan Gujarat yang didasarkan pada catatan perjalanan Marcopolo dan keberadaan mazhab syafi'i yang dianut oleh raja-raja pada kerajaan Samudera Pasai. Melalui para pedagang itulah kemudian hukum islam berkembang secara luas dan dianut oleh masyarakat Indonesia (Puti Yasmin, 2020).

\section{Qanun Aceh dalam Hukum Positif}

\section{Indonesia}

Sebagai negara dengan mayoritas pemeluk islam di dalamnya, penerapan hukum islam dalam tiap-tiap lini kehidupan masyakarat terlihat signifikan walaupun nyatanya hukum islam bukan sebagai sistem hukum utama yang digunakan di Indonesia, melainkan civil law sebagai hukum warisan Belanda yang
Desember 2021, Volume 7 Nomor 2

dianut sebagai hukum utama. Hal ini sejalan dengan teori reception in complexu sebagaimana diutarakan oleh Lodewijk Willem Cristiaan van den Berg yang memandang bahwa keberlakuan hukum islam secara penuh dilakukan bagi para pemeluknya yakni umat muslim walaupun dalam pelaksanaannya terdapat penyimpangan-penyimpangan (Normand Edwin Elnizar, 2019). Kebebasan untuk menggunakan hukum islam terlihat dalam konstitusi yakni ketentuan Pasal 29 ayat (2) UUD 1945 yang menyatakan kemerdekaan untuk memeluk agama dan kepercayaan bagi tiap-tiap penduduk Indonesia.

Hingga kini Aceh merupakan satusatunya wilayah dengan otonomi khusus untuk menjalankan syariat islam yang tercantum dalam konsiderans Qanun Aceh mengenai hukum jinayat yakni "Aceh sebagai bagian dari Negara Kesatuan Republik Indonesia memiliki keistimewaan dan otonomi khusus, salah satunya kewenangan untuk melaksanakan syariat Islam, dengan menjunjung tinggi keadilan, kemaslahatan, dan kepastian hukum". Selain itu, terdapat peraturan perundang-undangan lainnya yang melegalisasi kekhususan Aceh antara lain meliputi Undang-Undang Republik Indonesia Nomor 44 Tahun 1999 tentang 
Morality : Jurnal Ilmu Hukum

Penyelenggaraan Keistimewaan Aceh,

Undang-Undang Republik Indonesia

Nomor 18 Tahun 2001 tentang Otonomi

Khusus Bagi Daerah Istimewa Aceh sebagai Provinsi Nanggroe Aceh

Darussalam, Undang-Undang Republik

Indonesia Nomor 11 Tahun 2006 tentang

Pemerintahan Aceh, dan Undang-Undang

Republik Indonesia Nomor 48 Tahun 2007

tentang Penetapan Peraturan Pemerintah

Pengganti Undang-Undang Nomor 2

Tahun 2007 tentang Penanganan

Permasalahan Hukum dalam Rangka

Pelaksanaan Rehabilitasi dan Rekonstruksi

Wilayah dan Kehidupan Masyarakat di

Provinsi Nanggroe Aceh Darussalam dan

Kepulauan Nias Provinsi Sumatera Utama

Menjadi Undang-Undang.

Sebagaimana keberadaan undangundang secara umum, peraturan yang identik dengan Aceh adalah Qanun. Dilihat dalam ketentuan gramatikalnya, Qanun berasal dari bahasa Aab yakni Qaanuun yang berarti kompilasi, himpunan peraturan atau undang-undang, atau norma yang telah mapan (CR-3, 2005). Dalam konteks pelaksanaan hukum islam di Indonesia, Qanun merupakan peraturan perundang-undangan sejenis peraturan daerah (Perda) yang digunakan sebagai hukum penyelenggaraan pemerintahan dan kehidupan masyarakat Aceh. Karena
Desember 2021, Volume 7 Nomor 2

kedudukannya dipersamakan dengan Perda, maka isi Qanun dapat mencakup ketentuan pidana. Mengenai ketentuan pidana dalam Qanun ini tidak seperti ketentuan pidana pada umumnya dikarenakan mendasarkan bentuk penghukuman syariat islam yang pokoknya berasal dari $\mathrm{Al}$ quran dan Hadits. Oleh masyarakat Aceh, keberlakuan Qanun sangat diterima baik dengan alasan mencegah terjadinya malapetaka akibat dosa-dosa yang dilakukan melalui jarimah (tindak pidana), seperti misalnya minum-minuman keras (khamr), mengundi nasib dengan berjudi (maysir), dan berdekatan lawan jenis antara laki-laki dan perempuan yang belum menikah ke arah perbuatan mesum atau dikenal sebagai khalwat (Pane, 2016).

Keberlakuan Qanun bagi masyarakat Aceh dipandang memberi dampak positif bagi seluruh lini kehidupan. Seperti misalnya pengenaan hukuman cambuk mampu memberi efek jera khususnya bagi pelaku dan memberikan contoh kepada masyarakat agar tidak melakukan perbuatan tercela seperti yang dilakukan oleh pelaku tersebut guna memastikan kehidupan berjalan dengan damai sebagaimana mestinya (Nurbaiti et al., 2019). Masyarakat Aceh juga meyakini bahwasanya pengenaan hukuman tersebut 
Morality : Jurnal Ilmu Hukum

akan menghapus dosa-dosa atas perbuatan yang dilakukann oleh pelaku sebagaimana tuntutan syariat, penghukuman yang demikian juga dimaksudkan sebagai bentuk pertanggungjawaban perbuatan dosa yang dilakukan manusia di dunia.

Bagi sebagian orang yang memandang penjatuhan hukuman menurut Qanun bertentangan dengan HAM, oleh masyarakat Aceh justru dianggap bukan demikian adanya, melainkan sebagai wujud melaksanakan perintah Al-Quran, yang mana perintah tersebut berasal dari firman Allah SWT. secara langsung sehingga nilai keadilannya melebihi keadilan dalam pandangan manusia.

\section{Kedudukan Syariat Islam di Mesir}

Dalam konstitusi, syariat islam di Mesir memiliki kedudukan yang tinggi yakni sebagai sumber hukum utama negara. Namun yang terjadi dalam praktik tidak demikian, melainkan hukum islam hanya tergambar dalam bidang-bidang tertentu seperti hukum waris, munakahat, dan wakaf. Mengenai bidang lainnya seperti perdata dan pidana, hukum islam hanya dijadikan rujukan, bukan sebagai sumber hukum utama (Musyafaâ, 2012). Karena dikatakan bahwa seorang hakim Mesir dalam memutus perkara harus mendasarkan putusannya terhadap beberapa hal yang meliputi undang-undang
Desember 2021, Volume 7 Nomor 2

negara, adat kebiasaan, syariat Islam, undang-undang biasa, dan terakhir asas keadilan.

Suatu kekuasaan atau dinasti yang sedang berlaku di Mesir sangat memengaruhi hukum syariat islam yang berlaku. Hal ini karena pernah terjadi beberapa kali pergantian paham syariat islam seperti dari syiah ke sunni. Di masa modern saat ini, perkembangan pemikiran keagamaann di Mesir terbagi menjadi tiga antara lain Islam adalah agama dan negara, Islam hanya agama dan tidak mencakup negara, dan Islam adalah agama yang juga mengajarkan etika bernegara. Ketiga aliran tersebut dipengaruhi oleh kaum cendekiawan Mesir yang kebanyakan telah selesai menuntut ilmu dari negeri barat kemudian kembali ke negaranya. Meskipun demikian, tetap menjadi yang utama dan tidak diperdebatkan, bahwa syariat islam tetap menjadi landasan utama dengan kaidah, fikih, dan ijtihad ulama di dalamnya.

\section{B. Sistem Peradilan Pidana}

Dalam bentuk baku, KBBI mendefinisikan peradilan sebagai segala hal mengenai perkara pengadilan. Lebih lanjut, R. Subekti dan R. Tjitrosoedibio dalam pandangannya menyatakan peradilan sebagai suatu hal yang berhubungan dengan tugas negara dalam 
Morality : Jurnal Ilmu Hukum

menegakkan hukum dan keadilan. Sejalan dengan pandangan tersebut, Sjachran Basah juga mengaitkan peradilan dengan tugas memutus perkara melalui penerapan hukum, penemuan hukum in concreto dalam mempertahankan dan menjamin ditaatinya hukum materil, dengan menggunakan cara prosedural yang ditetapkan oleh hukum formal (Basah, 1995). Sedangkan pengadilan adalah badan atau organisasi yang diadakan oleh negara untuk mengurus atau mengadili perselisihan-perselisihan hukum (Bisri, 2000). Jenis pengadilan ini dapat berupa pengadilan umum maupun pengadilan khusus. Terkait dengan pengadilan khusus, yang menjadi kekhususannya adalah karena dibentuk dalam salah satu bidang peradilan di bawah Mahkamah Agung, seperti misalnya di bawah bidang peradilan agama, peradilan umum, peradilan militer, atau peradilan tata usaha negara.

1. Sistem Peradilan Pidana Islam di

\section{Indonesia}

Merujuk pada ketentuan Pasal 5 ayat (2) Qanun Nomor 5 Tahun 2000, pelaksanaan syariat islam meliputi berbagai bidang kehidupan seperti urusan muamalah, aqidah, ibadah, baitul mal, akhlak, pendidikan dan dakwah islami, syiar islam, kemasyarakatan, munakahat,
Desember 2021, Volume 7 Nomor 2

pembelaan islam, qadha, jinayat, dan waris. Terkait dengan upaya mewujudkan pelaksanaan syariat islam tersebut terlihat dengan adanya Peradilan Syariah atau disebut juga sebagai Mahkamah Syar'iyah yang didasarkan pada Keputusan Presiden Republik Indonesia Nomor 11 Tahun 2003 tanggal 3 Maret 2003 tentang Mahkamah Syar'iyah dan Mahkamah Syar'iyah Provinsi di Provinsi Aceh (Pane, 2016).

Kedudukan Mahkamah Syar'iyah dapat dinyatakan ganda sebab dipandang masuk kategori ruang lingkup dua jenis pengadilan, yakni pengadilan khusus dalam lingkup peradilan agama apabila menyangkut kewenangan agama serta berupa pengadilan umum dalam lingkup peradilan umum dengan kewenangan yang termasuk dalam peradilan umum. Namun demikian, penggolongan tersebut tidak lantas membuat Mahkamah Syar'iyah bebas dari kekurangan. Melihat praktik yang terjadi di lapangan, salah satu kendala Mahkamah Syar'iyah khususnya pada bidang jinayat adalah mengenai tidak adanya aturan khusus bagi Kejaksaan yang berperan sebagai Penuntut Umum untuk melakukan penuntutan ke Mahkamah Syar'iyah. Karena sebagaimana yang telah diketahui bahwa Kejaksaan ini berpedoman pada aturan KUHAP. Padahal dalam hal ini KUHAP hanya mengatur 
Morality : Jurnal Ilmu Hukum

hubungan Kejaksaan dengan Peradilan

Umum dalam rangka penyelesaian perkara pidana. Maka dari itulah baru kemudian Mahkamah Agung mengeluarkan Keputusan Nomor KMA/070/SK/X/2004 mengenai pelimpahan sebagian kewenangan peradilan umum kepada Mahkamah Syar'iyah dalam hal penyelesaian perkara yang terjadi pada subjek hukum yang beragama Islam dan perkara-perkara yang telah ditetapkan dalam Qanun Provinsi Aceh.

Mahkamah Syar'iyah sebagai pengadilan khusus memiliki perbedaan dengan pengadilan umum dalam tingkat pertama dan kedua. Pada umumnya, pengadilan pertama dilakukan oleh Pengadilan Negeri, kemudian tingkat banding dilakukan oleh pengadilan di atasnya, yakni Pengadilan Tinggi. Dengan konsep yang sama, Mahkamah Syar'iyah juga menangani banding oleh pengadilan yang lebih tinggi. Lantas yang sedikit berbeda adalah pengadilan tingkat pertama dilakukan pada Mahkamah Syar'iyah Kota atau Kabupaten, sementara tingkat selanjutnya pada banding dilakukan oleh Mahkamah Syar'iyah Provinsi.

Seperti misalnya dalam salah satu kasus dengan Nomor Register Perkara 16/JN/2021/MS Jth, yang mana Mahkamah Syar'iyah Jatho dalam hal ini
Desember 2021, Volume 7 Nomor 2

bertindak menjatuhkan putusan pada tingkat pertama terhadap pelaku jarimah pemerkosaan terhadap anak yang perbuatannya merupakan salah satu objek tindak pidana dalam Qanun Nomor 6 Tahun 2014 tentang Hukum Jinayah, sehingga kemudian Majelis Hakim dalam pertimbangannya memutus menjatuhkan hukuman ta'zir berupa 'uqubat penjara selama 180 (seratus delapan puluh) bulan demi mengurangi potensi Terdakwa mengulangi perbuatannya dan memberikan perlindungan kepada anak korban dalam kasus tersebut.

Sementara itu, dalam perbuatan lainnya yang termasuk dalam objek tindak pidana maisir atau secara umum dikenal sebagai perjudian, Majelis Hakim dalam perkara dengan Nomor 03/JN/2014/MS Mrd, menjatuhkan 'uqubat cambuk sebanyak 12 (dua belas) kali kepada Terdakwa yang dilaksanakan di depan khalayak umum (Meureudu, 2014). Penjatuhan hukuman ini bukan diberi untuk mempermalukan Terdakwa maupun keluarganya, tetapi lebih kepada pemberian efek jera dan contoh agar masyarakat menghindari perbuatan tercela tersebut.

Lebih lanjut, terkait dengan kewenangan Mahkamah Syar'iyah mengadili perkara pada tingkat banding, 
Morality : Jurnal Ilmu Hukum

salah satunya terlihat dalam kasus dengan Nomor Register Perkara 17/JN/2020/MS Aceh. Majelis Hakim yang mengadili perkara ini menyatakan Terdakwa terbukti secara sah dan meyakinkan bersalah melakukan perbuatan Jarimah pelecehan seksual terhadap anak sebagaimana diatur dalam Pasal 47 Qanun Aceh Nomor 6 Tahun 2014 tentang Hukum Jinayat dan menjatuhkan 'uqubat ta'zir penjara selama 24 (dua puluh empat) bulan. Sehingga, baik pada tingkat pertama maupun tingkat banding, dalam hal mana suatu perbuatan termasuk dalam objek jarimah dalam Qanun, Mahkamah Syar'iyah berwenang mengadili perbuatan-perbuatan tersebut.

2. Sistem Peradilan Pidana Islam di Mesir

Menilik dari sejarahnya yang panjang, Mesir dengan peradabannya yang terkenal maju, telah memiliki sistem peradilan sendiri sejak zaman kuno atau kurang lebih terjadi pada 3000 SM. Sistem peradilan yang digunakan pun layak mendapat predikat paling modern karena telah mengenal penggunaan asas-asas peradilan, karakteristik peradilan, proses administrasi, independensi hakim, dan lain sebagainya.

Sistem peradilan Mesir mempunyai 5 (lima) bentuk lembaga peradilan antara lain meliputi (Anshoruddin, 2016):
- Al-Mahkama ad-Dusturiyah al'Ulya (Mahkamah Agung Konstitusi);

- Majlis ad-Dawalah (Dewan Negara), yang meliputi Mahakim al-Qadha' al-'Idary (Peradilan Tata Usaha Negara), Qismu alFatawa (Komisi Fatwa), dan Qismu at-Tasyri' (Komisi Perundang-undangan).

- As-Sulthah Al-Qadha'iyyah/AlQadha' al-'Adiyah (Kekuasaan Yudikatif/Peradilan Biasa), yang meliputi Peradilan (Mahkamah) dan Kejaksaan (Niyabah).

- Hai'ah Qadhaya ad-Daulah (Lembaga Kasus-Kasus Negara);

- An-Niyabah al-Idariyyah (Kejaksaan Administrasif).

Di samping ke lima lembaga peradilan tersebut, ada juga peradilan istimewa (Exceptional Court) yang dikenal dengan Mahkamah Amnu ad-Daulah (Peradilan Keamanan Negara) yang mempunyai kewenangan mengadili perkara subversi dan pembunuhan terhadap Kepala Negara.

Tingkatan Peradilan dalam sistem peradilan pidana Mesir terdiri dari Peradilan Bagian (Al-Mahkamah AlJuz'iyyah), diketuai oleh hakim tunggal, yang berkewenangan memeriksa perkara 162 
Morality : Jurnal Ilmu Hukum

pidana dan perdata sesuai peraturan perundang-undangan yang berlaku. Peradilan Pertama (Al-Mahkamah AlIbtida'iyyah), merupakan peradilan ulang bagi al-mahkamah al-juz'iyyah yang mempunyai kewenangan mengadili perkara pidana dengan tuntutan selain denda atau tuntutan yang diajukan oleh jaksa penuntut umum. Peradilan Banding (Al-Mahkamah Al-Isti'nafiyyah), dilakukan dengan sidang suatu majelis dengan keberadaan 3 (tiga) orang anggota kanselir (al-Mustasyar). Peradilan Kasasi (Mahkamah an-Naqdh), berwenang mengawasi keabsahan penerapan hukum terhadap perkara yang dimohonkan kasasi sehingga memungkinkan meluruskan cacat penerapan hukum, dan menemukan kemaslahatan bagi para pihak atau kepentingan umum. Terkait dengan bidang pidana, permohonan kasasi dapat diajukan apabila terdapat kekeliruan hukum, cacat putusan, atau terdapat kesalahan penerapan hukum acara yang mengakibatkan cacat hukum (Anshoruddin, 2016).

Kejaksaan Agung (An-Niyabah al'Ammah). Penerapan prosedur proses permohonan kasasi melalui pra persidangan, Majelis Kejaksaan (anniyadah al-'ammah) dalam perkara perdata, pidana dan keluarga. Adapun Struktur organisasi Kelaksaan Agung yakni Jaksa Agung, Wakil-Wakil Jaksa Agung (Pengawas Peradilan), Jaksa-Jaksa Tinggi, Al-Muhamy al-'Am al-Awwal (Penasehat Hukum Pertama), An-Niyabah al-Kulliyah (Jaksa Umum), An-Niyabah al-Juz'iyyah (Jaksa Bagian), dan AnNiyabah al-Mukhtashshash (Jaksa Khusus).

Sementara dalam lingkungan Peradilan di Mesir tidak jauh berbeda dengan pembagian lingkup peradilan di Indonesia yang mencakup antara lain $\mathrm{Al}$ Mahakim al-Madani (Peradilan Perdata), Al-Mahakaim al-Jina'I (Peradilan Pidana), Al- Mahakaim al-Idari (Peradilan Tata Usaha Negara). Adapun ketiga lembaga peradilan di atas memiliki tugas dan wewenang yang berbeda sesuai dengan peranan dan fungsinya masing-masing (Anshoruddin, 2016).

\section{KESIMPULAN}

Berdasarkan seluruh penjabaran di atas, dapat ditarik kesimpulan bahwa antara peradilan pidana islam Indonesia yang diselenggarakan khusus di wilayah Provinsi Nanggroe Aceh Darussalam dibandingkan dengan peradilan pidana islam Mesir tampak memiliki kesamaan dengan kedudukan syariat islam yang digunakan sebagai sumber hukum dalam memutus perkara. Keberadaan Mahkamah Syariah di Aceh dapat dikatakan sebagai 
Morality : Jurnal Ilmu Hukum

wujud apresiasi akan hukum islam yang ditegakkan oleh masyarakat Aceh. Sehingga melalui otonomi khusus, mengecualikan dari pelaksanaan peradilan pada umumnya, hukum islam digunakan lebih spesialis dibandingkan hukum positif negara yang berlaku. Sementara pelaksanaan peradilan di Mesir juga menegakkan syariat islam yang mana bagian dari perintah konstitusi negara untuk menggunakan islam sebagai hukum utama, walaupun dalam pratik tidak menutup untuk digunakannya undangundang negara sebagai rujukan penjatuhan putusan oleh hakim.

\section{DAFTAR RUJUKAN}

Anshoruddin. (2016). Peradilan di Republik Arab Mesir. Pengadilan Tinggi Agama Pontianak. https://ptapontianak.go.id/e_dokumen/2016/Per adilan Di Republik Arab-Mesir_1 oleh Anshoruddin.pdf.

Arief, B. N. (2019). Perbandingan Hukum Pidana. PT Raja Grafindo Persada.

Atmasasmita, R. (2000). Perbandingan Hukum Pidana. Bandung: Mandar Maju.

Atmasasmita, R. (2009). Perbandingan Hukum Pidana Kontemporer. Fikahati Aneska.

Basah, S. (1995). Mengenal Peradilan di Indonesia. Jakarta: Raja Grafindo Persada.

Bisri, H. (2000). Peradilan agama di Indonesia. RajaGrafindo Persada.
CR-3. (2005). Kontroversi Qanun, Perda Dengan Karakteristik Khusus. Www.Hukumonline.Com. https://www.hukumonline.com/berita/ baca/hol13872/kontroversiiqanuniperda-dengan-karakteristik-khusus/

Glendon, M. A., Gordon, M. W., \& Osakwe, C. (1994). Comparative legal traditions: Text, materials, and cases on the civil and common law traditions, with special reference to French, German, English, and European law. West Group.

Meureudu, M. S. (2014). Petikan Putusan Perkara Jinayah No: 03/JN/2014/MS.Mrd.

https://www.ms-aceh.go.id/berita-seaceh/item/1418-ms-meureudupetikan-putusan-perkara-jinayah-no03-jn-2014-ms-mrd-7-4.html.

Musyafaâ, N. L. (2012). Penerapan Syari'at Islam di Mesir. Al-Daulah: Jurnal Hukum Dan Perundangan Islam, 2(2), 208-236.

Normand Edwin Elnizar. (2019). Jalan Berliku Hukum Islam di Indonesia. Www.Hukumonline.Com.

https://www.hukumonline.com/berita/ baca/lt5cf3e8f4aea82/jalan-berlikuhukum-islam-diindonesia? $\mathrm{r}=0 \& \mathrm{p}=1 \&$ $\mathrm{q}=$ hukum islam $\& \mathrm{rs}=1847 \& \mathrm{re}=2021$.

Nurbaiti, N., Wahyuni, W., Rizki, M., \& Nisa, H. (2019). Pandangan Masyarakat terhadap Pelaksanaan Hukuman Cambuk di Aceh. Indigenous: Jurnal Ilmiah Psikologi, 4(2), 96-104.

Pane, E. (2016). Eksistensi Mahkamah Syar'iyah Sebagai Perwujudan Kekuasaan Kehakiman. $A L$ 'ADALAH, 13(1), 39-52. 
Puti Yasmin. (2020). 3 Teori Masuknya Islam ke Indonesia Lengkap. Detik.Com.

https://news.detik.com/berita/d-51033 89/3-teori-masuknya-islam-ke-indone sia-lengkap.

Suherman, A. M. (2008). Pengantar Perbandingan Sistem Hukum.

Sunaryati, H. (1976). Kapita Selekta Perbandingan Hukum. Alumni, Bandung.

Susi Dwi Harijanti. (2014). Bolehkah Menggunakan Hukum Eropa Kontinental dan Anglo Saxon Bersamaan.

Www.Hukumonline.Com. https://new.hukumonline.com/ klinik/detail/ulasan/lt52d0dd1656749/ bolehkah-menggunakan-sistem-huku m-eropa-kontinental-dan-anglo-saxon -bersamaan/ 